\section{Walter Berns}

W alter Berns died on January 10, 2015. He was 95 years old. Berns was a constitutional scholar, a political philosopher, and a leading figure in the neoconservative movement. At the time of his death, he was a scholar at the American Enterprise Institute and a professor emeritus at Georgetown University. He was a National Humanities Medalist, awarded by George W. Bush in 2005.

Berns entered graduate school in 1950 at the University of Chicago, where he studied under Leo Strauss. Berns applied the classical tradition of Strauss to the study of political institutions. He was a student of American political thought, American democracy, and the American Constitution. For Berns, the development of virtue was a paramount goal of society and necessary to maintaining democratic government. His 2001 book Making Patriots sums up the challenge of liberal democracy: how to encourage freedom to be used in the service of promoting democracy and not just as a means of upholding individual rights. Berns presented the history of patriotism from the ancient Greeks and lamented that its inculcation through religion and education had been lost. He posited that patriotism and virtue must be taught, and looked to biography, particularly of the American patriot, Abraham Lincoln, to teach it.

His first book, Freedom, Virtue, and the First Amendment (1957), developed the idea that would be central to the rest of his work. That is, modern American law, society, and political thought overemphasize specific individual rights at the expense of cultivating a civic society that promotes the virtue of its citizens. Berns believed that individual rights, especially freedom of speech, could and should be limited. He vigorously defended censorship of pornography, maintained that the death penalty was not cruel and unusual punishment, and believed that the free exercise of religion should be used as a force to create good citizens. He was a prolific writer of books and essays, among them, The First Amendment and the Future of American Democracy (1985), Taking the Constitution Seriously (1987), and After the People Vote $(1983,1992,2004)$, an edited volume explaining the electoral college. His last book, Democracy and the Constitution (2006) was a series of essays on topics near and dear to his heart: natural law, inalienable rights, separation of church and state, and moral education.

Walter Berns was indeed an accomplished and influential scholar. But to this student of his, and to generations of his students, he was much more than that. He was a teacher. Walter Berns himself once said he was a "toughie." As anyone who knew him well understood his toughness was intellectual rigor, not rigid doctrinarism. He had a great mind, but he had a great heart as well. He loved his work, and he loved his students, and he held them to the same high standards he held himself. He was delighted when they met those high standards, even for a brief moment. His great baritone voice-really, he could have been a radio announcer or a Shakespearean actor-was not always gruff. He mesmerized his students in his classes on Constitutional law, Lincoln (he had memorized the Gettysburg address as a boy and was a lifelong student of Lincoln's political thought), and Alexis de Tocqueville. His students will remember him standing before the class expounding on Tocqueville's prescient observances on the differences between Europe and America, and lamenting the Americanization of Europe. "If you haven't been to Europe yet," he would loudly exhort, "go soon!" waving his hands in the air, and alarming them into making immediate plans for trans-Atlantic travel. Lest his students be offended by his neo-conservatism (and it was well-known among awed students that he played poker with Antonin Scalia and Robert Bork), he let them know that he had started out as a Marxist. "Workers of the world unite!" he would cry in class, demonstrating his youthful leftist days. He would tell stories, and joke, and laugh at himself, and make his students think, so that they could barely take notes. One just wanted to sit back and enjoy the intellectual ride, but one wanted to take notes too, so that one could remember everything he said.

Berns made the philosophers come alive. "Say what you will about him," he would cry out about some philosopher in class, "but he was a thinker." He put such a stress on the word "thinker," put so much emphasis on thought that it seemed there was nothing more important to be in the world than a thinker. And his students were in the presence of a great one. He would weave together amazing lectures, illustrating the readings by telling stories and quoting from old songs, and reminiscing about his youth and previous students. He really chuckled one day when he told of a student who came up to him after a lecture, clearly moved. The student was eager and excited and said breathlessly to Professor Berns, "That was the most enervating lecture I have ever heard!" Professor Berns paused, grinned, and then told his class, "I took it in the spirit in which it was intended." Of course he did. Professor Berns, was, if nothing else, a gentleman. And he was a gentleman who met students where they were, while encouraging them to reach higher. Berns would talk about Tocqueville and music "sublimating the passions." He said he had a hard time explaining that concept to students early in his career, but by the time rock and roll came around, students could understand. Yes, Walter Berns could use rock music to make his point about Tocqueville.

Walter Berns went to Reed College, the University of Iowa, and the London School of Economics (where he said he learned more about London than economics), and he served in World War II before ending up in 1950 at the University of Chicago. The University of Chicago changed his life. He studied under Leo Strauss and met and became lifelong friends with Herbert Storing, Allan Bloom, Martin Diamond, Robert Horwitz, and Ralph Lerner. He also met his wife, the former Irene Lyons. (He was particularly fond of referring to the old song, "Good night, Irene" in class). Berns talked about his debt to Chicago when he received his National Humanities Medal: "I owe a great deal to the University of Chicago. In a way I owe much of the happiness in my life to the university. It was there that I became aware of what my career should be; it was there that I met my closest friends, who remained my friends; it was there that I met my wife fifty years ago. And what can beat that?" Another student colleague of his was Harry Jaffa, who, born a year earlier than Berns, died within hours of him. The two, initially friends, had had a 
long-standing and bitter intellectual dispute. It seems somehow fitting that in death, they mirror Adams and Jefferson, bitter political enemies who died within hours of each other on July 4, 1826 (though Adams and Jefferson had a late-in-life reconciliation, which Jaffa and Berns did not).

Walter Berns' first teaching job in 1953 was at the University of Louisiana. From there, he moved to Cornell University in 1959. He stayed for 10 years but left in disgust at what he saw as the administration's capitulation to the demands of student protestors. Labelled a racist for being opposed to the black students' forceful takeover of the student union, he maintained that his freedom of speech in opposing the protests was being denied. After teaching at the University of Toronto for 10 years, Berns moved to Washington in 1979, as John Olin University Professor at Georgetown University and a scholar at the American Enterprise Institute. He remained in Washington for the rest of his life.

Berns is said to have been one of the founders of the neoconservative movement, though this is not a title that he claimed for himself. He railed against "the sacrifice of political relevance on the altar of methodology," and insisted on, well, taking the Constitution seriously. He encouraged his students to do the same. He read and re-read the document in class, making students think about what the words meant. And he mandated readings from the Federalist Papers, emphasizing the philosophical basis of the framers (he always said "framers," never "founding fathers"). He believed in the institutions of American government, and he taught that the Declaration of Independence created a people, but the Constitution created the government. He was a patriot who loved his country but understood that others could disagree about politics and still love the country, too. He was a conservative because he followed his thoughts to what he saw as their logical conclusions. He started from the thoughts, not from the conclusions. He was more concerned with right and logical thinking than he was with political labels, and he had little use for some of the neoconservative types that were prevalent in Washington during the Reagan years. On the night of the vice presidential debate between Dan Quayle and Lloyd Bentsen, he let his class go early so his students could watch the debate on TV. He grinned and said that he would be watching it over a martini (or perhaps two). Although no one asked him about it the next day of class, he must have loved Bentsen's line to Dan Quayle, "Senator, you're no Jack Kennedy," even though it scored points for the other side.

About his teaching style, one student recounts: "I first encountered Walter Berns in the fall of 1988, as a hapless graduate student who hadn't done the reading for the first day of his Constitutional Law class. 'Miss Cammisa,' I heard his baritone voice intone, 'what are the facts of the case in Marbury vs. Madison?' I somehow muddled through the answer to that, only to be completely flummoxed by his reading and rereading of Article III, Section 2 of the Constitution, asking me under what provision the case had come to the Supreme Court. Trick question: the case came to the Supreme Court under the Judiciary Act of 1789 , which is key, since Chief Justice Marshall used that as the basis for declaring the Act unconstitutional and thus establishing judicial review. Was I humiliated? Yes. Did I learn from the experience? Yes. Did Professor Berns offer me hope for redemption? Yes to that, too. To this day, I remain convinced that Dr. Berns saw something in that diffident graduate student that he wanted to draw out. As we were leaving class that evening, he announced, with what I now recognize as his characteristic grin, that the person doing the paper for next week's reading would be, of course,
'Miss Cammisa.' Miss Cammisa spent the remainder of the week holed up in the graduate student study room of the Lauinger Library, reading and rereading the cases, writing and rewriting her paper. And sure enough, Walter Berns was tough on her again. Only this time, Miss Cammisa was prepared. As I turned in my paper at the end of class, Professor Berns wasn't only grinning. He was smiling from ear to ear, his eyes a-twinkle. In a still somewhat gruff voice, he said, 'You certainly were on the grill tonight!' I certainly was. And I had done something I value more than almost anything else I did in graduate school: I had earned his respect."

That student was this author. Certainly, Berns' life, work, and teaching left an indelible mark his students. It is difficult to sum up Walter Berns in a few words. He was a gentleman and a scholar. He was a political philosopher and a professor. He was a neoconservative and strong in his beliefs. He was a man of honor, and "say what you will about him," he was a thinker. He was also a teacher, and one whose lessons are still being taught by the generations of graduate students who were taught by him, influenced by him, and inspired by him. The world has a lost a thinker, but his students will never really lose their teacher: his inspiration lives on as they teach the next generations of students. I am reminded of the words of Thomas More in A Man for All Seasons, when he advises Richard Rich to become a teacher, and Rich wonders who will even know if he is a good one. More responds: "You! Your pupils! Your friends! God! Not a bad public, that." No, not a bad public at all.

Walter Berns is survived by his wife of 63 years, Irene; two daughters, Elizabeth Fradkin and Emily Heyser; a son, Christopher; six grandchildren; and scores of admiring students.

-Anne Marie Cammisa, Georgetown University

\section{William K. Muir, Jr.}

W illiam K. "Sandy" Muir, Jr., professor emeritus in the department of political science at the University of California, Berkeley, died on February 26, 2015 at the age of 83. Sandy joined the department in 1968 after earning a JD at the University of Michigan and a $\mathrm{PhD}$ at Yale (while practicing law in New Haven). He taught courses in American constitutional law and American politics at Berkeley until 2012. He chaired the Department 1980-1983 and chaired numerous Academic Senate committees.

Sandy Muir was a superb teacher, twice receiving campus-wide outstanding instructor awards. He was also a remarkably inspiring teacher. Students responded enthusiastically to Sandy's classes partly because of the striking originality of his mind and his great personal warmth. Another reason was Sandy's optimism: he focused less on the flaws of democratic politics but more on the achievements and possibilities of American democracy, the resilience and creativity of American society, and the positive contributions of law and lawyers to governance. A third reason was that Sandy regularly prodded students toward active engagement with the world and, just as importantly, modelled that engagement himself, notwithstanding the physical limitations imposed upon his body by polio, which he contracted at the end of his senior year in college.

Muir was also a superb scholar. He published five highly original books, all written with literary grace, clarity, and a humanistic 
touch that is rare in the prose of the contemporary social sciences. His scholarship reflected an underlying normative concern: how to make governmental and legal institutions work well. He strove to define a good legislature, a good police officer, good leadership, a good judge-and to analyze what institutional arrangements and practices promote those virtues. To pursue that analysis, Sandy relied to a considerable extent on participant observation and in-depth interviews with relevant government officials.

Thus, to study the exercise of coercive authority, Sandy rode the streets in Oakland, California, in police cars. He spent hours with rookie cops, experienced cops, sergeants, and the departmental chief. With them, Sandy discussed the dilemmas and psychological challenges of exercising coercion. He gained an understanding of how the most skilled officers meet those challenges in a discerning way. He explored the modes of training and supervision that facilitate the moral maturation of successful officers. Sandy also served on the contentious Berkeley Police Review Board, where he himself had to decide precisely what the bounds of coercive power should be. Muir's prize-winning book Police: Streetcorner Politicians (University of Chicago Press, 1977) is a classic. To quote one reviewer: "Because of the philosophical depth he brings to his commentaries, [Professor Muir] has lifted the sociology of the police on to a new level." And he demonstrates how examining the microcosm of urban policing can illuminate the most fundamental issues of politics. Police was awarded the Hadley B. Cantril Prize and was nominated for a Pulitzer Prize.

To study the legislative process, Sandy worked for a year as a staff member on a California Assembly committee, sleeping at night on a couch in a member's office in Sacramento. During the day he argued with legislators about the wording of bills, met with lobbyists, interacted regularly with the talented assembly speaker Willie Brown, and learned what institutional norms and procedures promoted better policy-making. Muir's Legislature: California's School for Politics (University of Chicago Press, 1983) begins with a startling metaphor: "A legislature is like a school. It educates its members in the science of public policy and the arts of politics." Its classrooms, Sandy wrote, are committees-where lobbyists "expose legislators to a wealth of knowledge about human affairs." The legislative process, he added, teaches legislators about the day-to-day struggles and concerns of their constituents and thus teaches them empathy. "Service on committees, authorship of legislation, and specialization constitute the major elements of the legislative curriculum. Enlargement of intellectual horizons, improvement of negotiation skills, and cultivation of expertise result. ... When a legislature educates well ... it functions as a school of political capacity."

Muir's books sequentially examine three basic mechanisms that he saw as essential to governance-coercion (which he analyzed in Police), reciprocity (through which the legislators he described in Legislature accumulated power), and persuasion (or leadership). Persuasion was the focus of Sandy's first book, Law and Attitude Change (University of Chicago Press, 1974), which was based on his Corwin Award-winning PhD dissertation. At one level, Law and Attitude Change, like "impact studies" by other students of the US Supreme Court, sought to determine the conditions under which bold Court decisions could actually affect political and social behavior. But Muir's book also asked whether and when Court decisions-in this case study, Abington County v Schempp (1963), banning "religious exercises" in public schools-could also change the attitudes of political leaders and citizens. His answer was "yes-under some conditions." And he illustrated "how." Muir's book described how a school board attorney in a Midwestern city persuaded a majority of the board, which initially was firmly opposed to banning daily school prayer, to comply with the Court's ruling. The book thus highlights the way lawyers around the country, mobilized by judicial decisions, often serve as law-disseminators, as they invoke not only the threat of lawsuits but also judicially articulated principles and arguments to persuade local governments to change their policies.

Years later, to continue his study of leadership, Sandy spent a year in Washington as a working member of Vice-President George H.W. Bush's speech-writing staff-a perch from which Sandy could interact regularly with President Reagan's speech writers and analyze the ways in which presidents use their many opportunities for public persuasion. In his book, The Bully Pulpit: The Presidential Leadership of Ronald Reagan (ICS Press, 1991), Muir wrote:

"The tools of leadership are neither fear nor bribery, but thoughts. Leaders express ideas-ideas that explain events, create comradeship, and shape purpose. With articulate thought, leaders help others transcend their confusion, loneliness, and despair. A leader's ideas connect people to honorable objectives and inspire them to think purposefully, 'What action am I going to take?' instead of submitting hopelessly, 'What is going to happen to me?"'

By that standard, Sandy Muir used his office as teacher and scholar to be a political leader. Unlike most political scientists, Sandy strove not merely to explain the world, but to illuminate its possibilities and to inspire his students and readers to construct pathways to those possibilities. In 2014, a group of former undergraduate students established the Sandy Muir Leadership Award, now given annually to graduating UC Berkeley students with "an exemplary record of public service." More than 200 of Sandy's students, colleagues, and friends have contributed unprecedented amounts to that program, and it continues to grow-an outpouring of gratitude and admiration for an inspirational teacher, scholar, and person.

-Robert A. Kagan, University of California, Berkeley

\section{Donald B. Rosenthal}

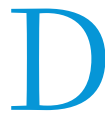
onald B. Rosenthal, professor emeritus of political science at the University at Buffalo (SUNY), died December 5, 2014, at his home in Charlotte, North Carolina. He was 77 years old.

A native of Brooklyn, New York, Don received his AB from Brooklyn College in 1958 and his AM from the University of Chicago in 1960. He joined the University at Buffalo (UB) faculty in 1964 as an assistant professor in the department of political science after receiving his $\mathrm{PhD}$ from the University of Chicago. He was promoted to associate professor with tenure in 1968 and full professor in 1972. A one-time chair of the department, Don taught and conducted research in the areas of the politics of India, American urban politics and intergovernmental relations, public policy, AIDS politics and policy, housing and community development programs, and public administration. He retired from UB in 2000 and moved to Charlotte, North Carolina, with his long-time partner David G. Scott.

A member of the American Political Science Association, Don served as chair of the association's Committee on the Status of Lesbians, Gays, Bisexuals, and Transgendered in the Profession from 
2000 to 2001 and was a member of several other APSA committees. He reviewed manuscripts accepted for publication by SUNY Press and Oxford University Press. During his career he published more than 30 articles in leading professional journals, including Journal of Politics, Midwest Journal of Political Science, Social Forces, American Sociological Review, Polity, and Urban Affairs Quarterly.

During his academic career, Don published several major scholarly books. The first, The Limited Elite: Politics and Government in Two Indian Cities (University of Chicago Press, 1971), was an empirical study of local elites in the Indian cities of Agra and Poona based on his interviews of several hundred local notables, municipal legislators, and national politicians. As a senior colleague noted, Don was the only person in $50+$ year history of his department to have published about India. That book was an expansion of his $\mathrm{PhD}$ dissertation at Chicago written under the tutelage of Lloyd and Suzanne Rudolph, among the most eminent American scholars working on India at that time. This was followed in 1978 by the publication of The Expansive Elite: District Politics and State Policy-making in India (University of California Press) which was an empirical field study of the institutions and rural elite in the Indian state of Maharashtra.

Don had a life-long interest in public policy, especially as applied to critical social issues. He started with a more classic interest in public administration and then broadened that interest to public policy. He was regularly engaged in several projects to bolster civic engagement. Above all, he recognized the importance of bringing personal commitment to scholarship, as exemplified in his widely recognized work on HIV-AIDS and gay rights, LGBTQ community activism, and the responses of New York State cities to the HIV/AIDS epidemic. That commitment continued long after his retirement from UB. Both before and after his retirement, Don was regularly engaged in projects to bolster civic engagement.

Don's third major scholarly work marked his turn to US public policy. Urban Housing and Neighborhood Revitalization: Turning a Federal Program into Local Projects (Contributions in Ethnic Studies) was published in 1988 by Praeger Publishers whose description of the book points to its importance at the time of publication: "Although many scholars have emphasized the shortcomings of federal housing programs, few have examined their successes and failures on a case-by-case empirical basis. With the possibility that federal involvement in housing may increase in the future, we need to have more precise knowledge of what works, what does not, and why. Donald Rosenthal's new book is the first study to focus on the Section 8 Neighborhood Strategy Area program (NSA)—one of the last major housing initiatives of the Carter administration. Reporting on his extensive field research, the author examines the development and implementation of the program and documents its results. In the process, he provides valuable new insights on American intergovernmental relations between 1977 and 1984 and traces the evolution of federal policy on assisted housing and community development under the Carter and Reagan administrations."

Don's decades of research on the history of LGBTQ activism and the AIDS crisis has been preserved in the M. E. Grenander Department of Special Collections \& Archives of the University Libraries at the University at Albany (SUNY). As described by the University at Albany Libraries, the Donald B. Rosenthal Papers, 1982-2004, "include an extensive collection of interviews with Capital District activists, an assortment of print publications regarding AIDS, and a series of material documenting the activities of the Capital District Gay \& Lesbian Community Council (CDGLCC). The results of Rosenthal's research are represented by a collection of his own papers and lectures on gay activists' role in municipal politics and their responses to the spread of AIDS." A detailed description of the contents of each of the four series of papers in the collection can be found on the Internet under the name Donald B. Rosenthal.

Following Don's retirement and move to Charlotte, North Carolina, he and his partner David engaged in the study of LGBTQ issues, civil rights, and homelessness in North Carolina (especially RaleighDurham), Alabama, and Louisiana in conjunction with the ACLU. Their collected papers concerning this research are on deposit at the Duke University Libraries in Durham, North Carolina.

Several colleagues have shared their recollections of Don. One recently stated, "My strongest impressions of Don will surely not be mine alone. He was an energetic, fastidious, and rigorous political researcher who was drawn to understand the sources of disadvantage in America and abroad, who asked difficult questions, and who was interested in drawing policy-relevant conclusions from his work. $\mathrm{He}$ was simply one of the most caring, fun-loving, and generous souls a person could ever encounter. His playful banter in the halls of the department made it a wonderful, welcoming place to join as a junior faculty member. Don had many sterling qualities but he was not, however, a good driver! One of my most vivid memories of Don arose on the occasion of my on-campus interview in 1989. As chair of the department, Don met me at the airport and I recall my terror when he had shifted his manual transmission rapidly into third gear before we had even reached 10 miles an hour and while still in the small airport parking lot! I will never forget how his car bucked and groaned under the strain. Over the course of my visit it seemed like we must have covered 500 miles in his car (safely, thank heavens!) as he tirelessly toured Buffalo with me, sharing his favorite spotssometimes several times when we became lost and had to retrace our route! It is therefore somewhat fitting that he was late arriving to what was to become our last rendezvous in Ohio last summer as the result of becoming lost and driving an additional three hours to meet us at our destination! Despite being thus challenged, however, he spent many happy days travelling the back roads of the United States with his beloved partner, David Scott."

Another remembered that Don generously mentored colleagues who sought his help, in matters both large and small. "He supported me at significant junctures in my career, even recently, as he was dealing with the last challenge to his health. He also encouraged a line of research I was hesitant to pursue. Even after he retired he continued to provide me with valuable insights. My work was always improved by his suggestions."

Recalling Don's gentleness, quirkiness, and sly sense of humor, another colleague also observed that "there was no meanness in Don. He was a sweet and kind person and a devoted scholar. All told, he was a fine person with a good heart. It was his goodness and sweet nature that stand out for me."

And yet another colleague recalled a former dean of social sciences at UB telling him that Don was undoubtedly the most selfless chair with whom he had worked in that he never asked for anything for himself (extra time off from teaching, salary increments, etc.) but only for his department. Don was quite willing to serve two stints as chair at a time when both the department and the social sciences more generally were seriously squeezed for resources. He was a member of the UB Faculty Senate and was a member of several Faculty of Social Sciences committees.

Don Rosenthal was a sweet, gentle, kind, and good person with a subtle, understated (some might say sardonic) sense of humor. That will always be our memory of him. He will be remembered as 
well for his excellent music collection, loyal friendships, and love for life. Don was a highly respected colleague and a beloved friend. He is sorely missed.

- D. Munroe Eagles, Frederic J. Fleron, Jr., Stephen C. Halpern, Claude E. Welch, Jr., Frank C. Zagare, Department of Political Science, University at Buffalo (SUNY) -Laurie Rhodebeck, Department of Political Science, University of Louisville

\section{Patrick Riley (1941-2015)}

T he political theory firmament lost a bright star with the passing of Patrick Riley in Cambridge, Massachusetts, on March 10, 2015. Patrick was suigeneris, a scholar of keen perception and astounding insight and a man of boundless generosity and kindness. He will be sorely missed.

Patrick Thomas Riley grew up in southern California and enjoyed regaling colleagues and students with tales of his exploits as a young man, from cruising Sunset Boulevard wearing wraparound sunglasses and driving a convertible to learning Latin from Tom Laughlin, Kung Fu master and star of the Billy Jack films. A graduate of Claremont Men's College, Patrick briefly pursued training in conducting at the Mozarteum in Salzburg (evidence of an abiding love of classical music almost as passionate as his love for the study of political philosophy). The music world's loss was the academy's gain, however, and Riley went on to the London School of Economics, where he studied under Michael Oakeshott and received an M.Phil. in 1964. Completing his $\mathrm{PhD}$ under the direction of Judith Shklar, Riley received his $\mathrm{PhD}$ from Harvard University in 1968. For many years, he held the Michael Oakeshott Chair in Political Science at the University of Wisconsin-Madison. He retained a lifelong association with Harvard as well, where he continued to teach during summers and after his retirement from Wisconsin in 2007.

Riley's scholarly interests ranged across the canon of ancient and modern political theory. His Will and Political Legitimacy (Harvard University Press, 1982) subjected the social contract tradition to sustained critical-but, as in all Patrick's work, sympathetic-analysis, ranging from Augustine up through his beloved Kant (whom Patrick had earlier declared, in a 1973 Political Theory article, to be "the most adequate" of social contract theorists) and Hegel. Though Kant was likely closest to his heart, his most profound contributions were probably made to the study of Leibniz, whom Patrick almost singlehandedly reintroduced to political theorists as a thinker worthy of their serious attention. The study of Leibniz's thought occupied Patrick for more than four decades, beginning with his edition of Leibniz's Political Writings for Cambridge University Press in 1972 through his Leibniz's Universal Jurisprudence:Justice as the Charity of the Wise (Harvard University Press, 1996) and a plethora of reviews and essays since then. It is no surprise, given Patrick's extraordinary devotion to Leibniz, that the editors of the Leibniz Review dedicated their 2011 issue to him. He remained engaged in the study of Leibniz until the end of his life: indeed, the most recent Leibniz Review contains both a substantive article by Riley, on Leibniz's Monadologie, and several remembrances of Patrick's life and career by friends and colleagues.

In addition to serving as editor of the Cambridge Companion to Rousseau (Cambridge University Press, 2001), Riley was the author of The General Will Before Rousseau (Princeton University Press, 1986), which left an indelible mark on the field and served as the organizing theme of a conference in his honor, held in Madison in October 2008. The papers presented at that event were published just before his death, in a volume edited by James Farr and David Lay Williams (The General Will: The Evolution of a Concept [Cambridge University Press, 2015]), which also contained two substantial articles by Riley revisiting the insights of his earlier work on this central topic in modern political theory. It seems somehow fitting that this volume appeared shortly before Patrick's death, as Rousseau's notion of the volonté générale had provided the basis for his first published article ("A Possible Understanding of Rousseau's General Will," APSR 1970). Along with his own prolific and erudite works of original scholarship, Riley was also instrumental in producing scholarly translations and editions of such thinkers as Leibniz, Fenelon, Bossuet, and Malebranche, providing the first available English-language translations of a number of important texts.

But merely reciting Riley's many books, articles, and scholarly contributions does not begin to communicate the essence of the man who left such a lasting impression on so many over the years. To generations of undergraduate students at the University of Wisconsin, Riley's lectures were the stuff of legend, as the Western canon came alive in 50-minute bursts from an engaging guide who regularly asked their permission to "remove one garment" before commencing. (He was, he always assured them, only referring to his tie.) The thinkers the students would encounter in his class, Riley would announce on the first day of the semester, were "dead...but only in the most trivial sense of that word." And he approached those texts and thinkers with a hermeneutic of charity that enabled him to demur from ideas he found unconvincing, while affirming their justified place in the canon, by describing their author's views as "perhaps more ingenious than persuasive."

To so many colleagues, and especially to graduate students, Patrick was a breath of fresh air, an esteemed colleague without a shred of self-importance, an internationally known scholar possessed of an impish sense of humor who was never too busy to lend a hand or offer an encouraging word. (This former student remembers him arriving with an air conditioner and insisting on installing it into the window himself, without ever removing his tie, to bring some relief to a pregnant spouse during the hot Madison summer of 1995; after the completion of which task, Patrick got back into his car and raced off to the airport to catch a flight to Boston.) As numerous colleagues and former students pointed out on the Internet in the days following his death, Patrick Riley did not simply study the great theorists of charity and justice-he aimed to live by those teachings and to treat those around him in accordance with the dignity he believed that all humans possessed. The study of Kant's Kingdom of Ends or Leibniz's notion of justice as the "charity of the wise" was, for Patrick Riley, both a theoretical undertaking and a lived practice.

-Andrew Murphy, Rutgers University

\section{T. Alexander Smith}

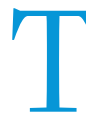
Alexander Smith, 78, of Reidsville, North Carolina, died Friday, December 26, 2014, following a lengthy illness. An undergraduate at Wake Forest University (1960), Alex received his MA at Cornell University (1963) and his $\mathrm{PhD}(1967)$ at 
Ohio State University. He previously taught at McMaster University in Ontario, Canada, and at Washington and Lee University in Lexington, Virginia, before joining the political science faculty at the University of Tennessee, Knoxville, where he remained for the rest of his academic career.

Sandy has lost her beloved husband; I have lost a coauthor; and students of morality politics have lost a pioneering spirit to whom we all owe an intellectual debt. T. Alexander Smith opened our eyes to the importance of moral conflicts in political life and their impact on the policy process. His dissertation on " $L$ Union Pour La Nouvelle République: Gaullism in the Fifth Republic" Alex dedicated to professor Edgar S. Furniss, the original committee chairman whose tragic death necessitated that the work be completed under the stewardship of professor James A. Robinson. Even before finishing his dissertation Alex had published "Algeria and the French Modérés" in the Western Political Quarterly (March 1965).

Despite his solid grounding in European comparative politics, Alex shifted his analytical focus in The Comparative Policy Process based on his "conviction that students of comparative politics devote insufficient attention to theorizing about the policy process." ${ }^{1}$ That was his most influential work, I believe, and he was surely influenced by James B. Christoph, who also served on the OSU faculty during the period when Alex was there. In 1962, Christoph published an article and monograph on the controversy over abolishing capital punishment in Great Britain. The debate over abolition of capital punishment was highly normative, and Alex took note of that unique feature of political combat in The Comparative Policy Process, which detailed case studies from the United States, Canada, and Europe that extended the policy typology developed by Theodore J. Lowi. The Lowi typology is now virtually a truism in policy studiesdistribution, regulation, and redistribution-though Alex modified Lowi's scheme. Distribution and redistribution were retained, and his politics of "sectoral fragmentation" was very close to Lowi's view of regulatory policy. But fundamentally different, and vastly more important, was his "emotive symbolic" policy type, which Alex illus trated with case studies of the civil rights controversy in the United States, the European Army debate in France, and the heated parliamentary conflict over redesigning an indigenous national flag for Canada. Where most policies implicate left-right economic cleavages in a society, "emotive symbolic" policies "generate emotional support for deeply held values, but unlike the other types considered in this work, the values sought are essentially noneconomic." ${ }^{2}$ Those insights, which continue to drive contemporary research on morality policies, have spawned a cottage industry in the subfield of public policy analysis. Ultimately, Lowi incorporated that perspective in his policy typology in 1988,3 and this mutuality of research interests prompted Alex and me to coauthor our Cultures at War, arguably the first systematic analysis of moral conflicts in the United States, Great Britain, France, Germany, and Canada. ${ }^{4}$

Alex also authored on race relations and economic theory. His book Time and Public Policy was an innovative treatise on the impact of time horizons on public policy. ${ }^{5}$ It was a featured selection of the Ludwig Von Mises Institute and reflected Alex's long-time study of, and contribution to, the Austrian School of economic theory. After retiring from the University of Tennessee and moving back to Reidsville, he spent several years as a member of the Board of the Museum and Archives of Rockingham County. Alex was a warm, fun-loving person who treasured the time he spent with friends, colleagues, and students, and particularly valued his close-knit group of fraternity brothers, who affectionately called him "Shaky." Surviving are his wife, Sandy Smith of Reidsville; daughter, Karen Norton and husband Bob of Los Angeles, California; son, Sander Smith and wife Linda of Winston-Salem; and grandchildren, Alex, Graham, Emma, Piers, and Alexandra (Lexi).

\section{-Raymond Tatalovich, Loyola University Chicago}

\author{
NOTES \\ 1. ABC-CLIO Press, 1975 , p. v. \\ 2. Ibid., p. 90 . \\ 3. Theodore J. Lowi, "Foreword: New Dimensions in Policy and Politics" in Raymond \\ Tatalovich and Byron W. Daynes, eds., Social Regulatory Policy: Moral Controversies in \\ American Politics. Boulder, CO: Westview Press, 1988. \\ 4. T. Alexander Smith and Raymond Tatalovich, Cultures at War: Moral Conflicts in \\ Western Democracies. Peterborough, Ontario: Broadview Press, 2003. \\ 5. University of Tennessee Press, 1989.
}

\section{Warren Weinstein}

W arren Weinstein, political scientist, aid worker, humanitarian, and modern Renaissance man, was killed by a drone strike on a suspected Al-Qaida compound in northern Pakistan in January 2015. He had been a hostage since August 2011. Italian aid worker and hostage Giovanni Lo Porto died with him, along with several alleged AQ members.

The writers, all friends and colleagues in political science, grieve for Warren Weinstein's death. But here we celebrate his life, and particularly his career in political science, in and beyond academia. Warren earned his Bachelors at Brooklyn College, and his Masters and $\mathrm{PhD}$ at Columbia University (1970), focusing on international economics and law. His dissertation research was done in the thenrecently decolonized Belgian colony of Burundi, beginning a long involvement with African issues.

With doctorate in hand, Warren moved to State University of New York (SUNY) at Oswego for a decade-long teaching and research career. Oswego colleagues remember him as a passionate, caring man with a heart as big as the borough of Brooklyn where he was born and raised. Bill Scheuerman, seconded by Bruce Altschuler, recounts those years:

I met Warren in the fall of 1974 after leaving the hustle and bustle of New York City to start my academic career at SUNY-Oswego, a rural campus deep in New York's snowbelt. The transition from an urban to a rural lifestyle wasn't easy, but it was made easier, and even pleasant, by the kindness of Warren and Elaine Weinstein. They mentored my wife and me as if we were family, teaching us the ins and outs of small town living, what shops and restaurants to go to and which to avoid. Warren helped integrate me into the academic community by bringing me into his circle of friends. A group of us would meet at the local Chinese restaurant. Warren usually took command, overseeing our orders and coordinating our choices in this collective meal. It was fun watching him.

We also spent manyweekend afternoons at the Weinsteins' house in Scriba, New York, talking and enjoying meals that Warren prepared. He loved cooking, eating, and gardening. I remember the smile on his face 
when he proudly showed me his enormous red canna lilies. His daughters, even though just little tykes at the time, were always present at these events, and Warren would shower them with displays of love and affection. He indulged them with toys to the extent that it was sometimes difficult to navigate your way through the house.

Warren's kindness toward me was simply part of how he lived. Over the years I saw Warren and Elaine repeat this kindness to other new faculty, some of whom actually stayed with the Weinsteins until they found a permanent residence.

Kindness and caring were Warren's hallmarks, but there was more to the man than this. Much more. Warren was an extraordinarily talented individual. He often spoke of his adventures in Africa and his commitment to helping the poor while in the Peace Corps, and it became crystal clear that he was an individual committed to making the world a better place without fear of the consequences. He was actively involved in promoting human rights, a cause that was fundamental to his existence.

Warren was a prolific scholar, focused on African issues. He frequently collaborated with another Oswego colleague, Robert Schrire, for example on "Political Conflict and Ethnic Strategies," a case study of Burundi. He published Chinese and Soviet Aid to Africa, updated several years later with Thion Henrikson, and a study, The Pattern of African Decolonization: A New Interpretation, coauthored with John J. Grotpeter. All of these books, and his articles in scholarly journals, were well received.

An energetic advocate of scholarship and professionalism who could get things done, Warren was the conscience of our political science department. He assumed this role almost immediately upon his arrival in Oswego by convincing the college president to sponsor an interdisciplinary conference, which Warren organized. When one of the major panels failed to meet his expectations, he intervened and guided the discussions to a satisfactory conclusion. In short, even as a new, nontenured academic, Warren was not reluctant to take on a major task and provide constructive criticism to colleagues. He set the standard for junior faculty to emulate.

It was a sad day when Warren left SUNY, although we all knew that he was destined to move on to a larger canvas. He loved wrestling with ideas and living the life of the mind, but that was not enough. His burning desire to make the world a better place would take him to dangerous places in the far corners of the world. His humanitarian legacy is now widely known, but those of us who were mentored by him as junior faculty will always remember him fondly as a friend and colleague who opened his big heart to us.

Leaving academic life did not mean that Warren abandoned his interest in political science. He continued to research and write for many years, publishing Historical Dictionary of Burundi with Ellen Eggers in 1997. Robert Schrire, an Oswego colleague and principal collaborator who later taught in South Africa, was hoping to resume some projects with him when he returned from his captivity. Schrire writes about working with Warren:

One of his most prominent characteristics was his generosity. He had written a monograph on Burundi's ethnic conflict, which required stylistic editing and the addition of a theoretical framework. I was happy to provide this and Warren insisted that I be listed as the co-author. This seemed to me to be unfair to Warren who had written most of the monograph by himself. This was one of the few arguments I won-I was listed as a collaborator and not coauthor!

We had many plans to work together on projects after his career in Pakistan had come to an end. Alas, this was not to be. Warren was one of a kind. Despite being a born and bred New Yorker, he had an innocence about people. He expected the best from them despite the number of times they disappointed him. Lacking the self-protection of cynicism, he literally gave his life in his efforts to make the world a better place for the poor and disadvantaged.

In his subsequent career, Warren remained focused on the issues that had animated his research and teaching-African politics, human rights, and economic development. As Schrire recalls, "Warren was one of the very few Westerners who genuinely understood and loved Africa: its people, art, languages, and culture." With his young family in tow, he served as director of the Peace Corps operations in Togo and Ivory Coast. Here, his tremendous language skills came into play, as he was able to interact with locals in French, the national language of those former French colonies.

This intense interest in languages was one of the hallmarks of his life; he became fluent in at least seven languages and willingly tried many more. One of us recalls Warren's gleeful recounting of a long bus ride in west Africa, which led to a dinner invitation from the bus driver, and no doubt some language lessons. His remarkable facility with languages enabled him to communicate with local people in ways most of us in the diplomatic service could never attain. Everywhere he lived and worked, from the very early days in ex-Belgian Africa, Warren sought to share the local culture and language.

Following the Peace Corps work, Warren joined USAID to give some expression to his great interest in helping bring about economic development in ways that would benefit a nation's entire population, not just the economic elites. He spent more than a decade in USAID working to advance this goal. Next came the International Finance Corporation, the development arm of the World Bank, where he drew on his training in international finance. He then moved more directly into development projects, working for a firm hired by USAID to assist its program in Pakistan. After seven years, he was just preparing to conclude this assignment when he was kidnapped. Sadly, as Robert Schrire notes, this happened in part because "Warren was one of a kind. Despite being a born and bred New Yorker, he had an innocence about people. He expected the best from them despite the number of times they disappointed him. Lacking the self-protection of cynicism, he literally gave his life in his efforts to make the world a better place for the poor and disadvantaged."

Warren was full of life, sometimes so exuberantly so that it was almost overwhelming. He had a boundless love for his wife Elaine and his daughters Jennifer and Alisa, and was saddened that living so far away he could barely know his two young grandchildren. In his last message to one of us, he said that he was looking forward to being at home and maybe not even leaving the house for a while! Elaine and her daughters spent the years of his captivity working to free him, never giving up hope despite the sad changes in Warren that were visible in the videos released by his captors.

Warren's infectious laugh could quickly shift a dark mood, and he enjoyed telling stories that poked fun at silly things he had done. He was renowned for his love of spicy foods, which continued into his time in Pakistan. Long ago one of us took him to a Thai restaurant in Alexandria, Virginia, where he devoured a bowl full of hot peppers as if they were peanuts. The incredulous kitchen staff came out to watch him tossing them down! Friends commenting from Pakistan talk about seeing him amazing the locals in the same way.

He was accepted and loved by so many, and social media has made it possible for their grief to be shared. Tributes from many countries have been posted. Two examples from Pakistan: 
"I read this news with great sorrow and share with you that he was like an elder brother to me. He will live in our hearts forever."

"He wanted to contribute to change, and it breaks my heart when I think that he is no more."

The world has lost a wonderful man who acted on his beliefs even though it meant putting his life and liberty at risk. Political scientists will be the poorer without him as a guide to making our chosen field relevant to coming generations of students.

-Bruce Altschuler, Professor Emeritus, SUNY-Oswego -Marshall Carter-Tripp, Foreign Service Officer (retired) -William Scheuerman, Professor Emeritus, SUNY-Oswego -Robert Schrire, Professor Emeritus, University of Cape Town -Stephen L. Wasby, Eastham, Massachusetts

\section{Raymond E. Wolfinger}

$\mathrm{R}$ aymond E. Wolfinger was a top notch scholar, mentor, and contributor to the discipline. He stood out as one of the very best $\mathrm{PhD}$ students of one of the very best political scientists of the 2oth century, Robert Dahl. Ray and his colleagues at Yale University contributed to a transformation in political science, bringing the systematic study of political behavior to the forefront and using the behavioral approach to answer important questions regarding the exercise of political power in a variety of settings: in cities, in Congress, and in elections. Later Ray became one of America's foremost students of voter turnout and played a crucial role in making the political science department at University of California, Berkeley, one of the best in the world. His many books and articles-often coauthored with his graduate students-set multiple agendas for future generations of scholars and students.

\section{LIFE AND CAREER}

Ray was born in San Francisco on June 29, 1931. His father died when Ray, an only child, was five or six. Ray spent his childhood in the Bay Area except for two years after Pearl Harbor, when his mother, a civilian army employee, was evacuated to Salt Lake City.

After graduating high school at the age of 15 , Ray enrolled at UC Berkeley and participated in ROTC throughout college. Upon graduating in 1951 he was commissioned as a second lieutenant in the army. Rather than being sent to Korea, Ray was stationed in eastern Washington in command of an anti-aircraft detachment with orders to protect the nuclear reactor there against Soviet bombers. (A subsequent military assignment involved interdicting the road at the Three Judges Motor Lodge in New Haven in case of invasion.) A couple of years later when he was in the reserves, Ray was driving across the country and stopped in Champaign-Urbana to see an army buddy. The friend was attending graduate school in political science there and encouraged Ray to enroll. For lack of a better idea, he did.

A solid C student in college, Ray found himself getting straight As in graduate school. Austin Ranney, his mentor at the University of Illinois and, much later, his colleague at UC Berkeley, advised him to finish his studies at Yale. In New Haven, Ray was in a cohort of exceptional students that included Fred Greenstein, Nelson Polsby, and Aaron Wildavsky. At Yale, Ray was a student of Robert Lane, Ed Lindblom, and Robert Dahl. Dahl eventually became his mentor and lifelong friend, even attending Ray's retirement celebration at the APSA Annual Meeting in 2006 at the age of 91.

In 1960 Ray, newly married, worked for representative Sidney Yates and senator Frank Church as an APSA Congressional Fellow. He spent the following year in Palo Alto as a fellow at the Center for Advanced Study in the Behavioral Sciences. Stanford hired him as a visiting faculty member in 1961 and then in a tenure-track position in 1962. Ray spent 1964 working for the Democratic Majority Whip in the Senate, Hubert Humphrey, where his primary job was assisting with the drafting and passage of the Civil Rights Act. (He initially had a desk in Humphrey's actual office, but was kicked out for being too messy.) During the year, he conducted interviews for a book on the Civil Rights Act; he once told one of us that he had managed to interview everyone involved with the passage of the Act except LBJ and Everett Dirksen.

After his return to Stanford, Ray was granted tenure in 1966 and promoted to full professor in 1970. In 1971 he was offered a job at UC Berkeley for the second time, and this time he accepted it. Ray spent the remainder of his career there, retiring as Heller Professor of Political Science in 2006.

\section{SCHOLARLY ACHIEVEMENTS}

Ray's scholarly career spanned 50 years and included more than 30 collaborators. His first publication was an article coauthored with a fellow graduate student, Fred Greenstein (Greenstein and Wolfinger 1959). The paper analyzed urban and suburban partisanship in an attempt to determine whether suburban Republicanism was the result of Republicans moving to the suburbs or due to the effect of living in the suburbs on partisanship. His last publication, written with his son Nick (Wolfinger and Wolfinger 2008), was an article examining the effects of marriage and family structure on voter turnout. In between, Ray authored, coauthored, or edited nine books and approximately 50 articles and book chapters, including 10 pieces in the American Political Science Review. His significant scholarly contributions span multiple fields within the study of American politics, including urban politics, ethnic politics, the policy-making process, Congress, public opinion, and political behavior.

Ray's first book, The Politics of Progress (Wolfinger 1974), was described by Robert Dahl as the "companion volume" to Who Governs? The book emerged from Ray's dissertation research, including a year of working for New Haven mayor Richard Lee. The empirical focus of The Politics of Progress was the development and implementation of urban renewal and redevelopment policies in New Haven. The central goal of the work was to test leading theories of policy making, interest group influence, and urban politics. Scholars like Arthur Bentley, Earl Latham, and David Truman emphasized the power of organized interest groups on the policy-making process. Others like Floyd Hunter and C. Wright Mills focused on private "elites" who used the institutions of government to advance their interests. Ray found neither approach fit with the evidence. One of his central findings was that politicians-the mayor in particularwere the most influential actors in the process, which is not what the "elitist" or "group" theorists would have predicted. "While there are important points of controversy between the group and elitist schools, the two share a belief that politicians are unimportant... But in New Haven the mayor played the leading role in policy formation, activating and manipulating interest groups. More than anything else, urban renewal policy resulted from his ambitions, not those of private groups" (Wolfinger 1974, 12). Arriving at this conclusion entailed extensive analysis and contributions in areas of 
ethnic and machine politics, which are also addressed in two articles (Wolfinger 1963; Wolfinger 1965).

Ray also conducted important research on party identification in the mass public. In addition to his first publication (Greenstein and Wolfinger 1959), he collaborated with five UC Berkeley graduate students on a conference paper, a journal article, and finally a book on partisanship in the United States (Keith et al. 1977, 1986, 1992). The central question they sought to address was how to interpret the growth in the number of people who considered themselves "independent" voters. By the 1970s, one in three Americans identified as independent, and many scholars and pundits predicted a host of potentially calamitous consequences: political instability, the collapse of the party system, and even the "loss of democracy" (Pomper 1977, 41).

Ray and his students found that the vast majority of people who said they were "independent" nevertheless thought and behaved like partisans. These independent "leaners" constituted most of the people identifying as independents, leaving true or pure independents at just around $10 \%$ of the electorate. What most people thought about the political significance of the growth in independents was not consistent with the evidence. Ray and his collaborators' careful empirical work made it clear that whatever the causes, the growth in political independents meant little politically.

Ray's most enduring research interest was voter turnout. He studied the demographics of turnout, analyzed the effects of registration and voting laws on turnout, examined the political consequences of unequal turnout among groups, contributed to the development of the "motor voter" provision of the National Voter Registration Act of 1993, and made it a focus of his remarks when dining at the White House with President Clinton and several other eminent political scientists.

Ray's work on turnout began with Steven Rosenstone, at the time a UC Berkeley graduate student. The two took advantage of the fact that in addition to its extensive collection of demographic variables, the Census Bureau's Current Population Survey (CPS) included registration and turnout questions in November of election years. They supplemented the CPS data with a detailed compilation of data on voter registration laws across the states. After combining the datasets, they were able to analyze turnout with both individual-level and state-level (registration laws) predictors. No one had done this before. Their research led to an article in the American Political Science Review (Rosenstone and Wolfinger 1978) and Ray's best known and most influential work, Who Votes? (Wolfinger and Rosenstone 1980). The book is notable for its attention to the separate and joint influences of laws and individual characteristics on turnout. Reviewing Who Votes? in 1981, Stanley Kelley wrote, "I do not expect soon to see a book that surpasses the achievements of this one" (Kelley 1981, 219). Judging by the book's more than 2,600 scholarly citations, he was correct.

Ray's work with Rosenstone concluded with Who Votes?, but his research on turnout continued with many other Berkeley students. With David Glass and David Magleby, Ray coauthored an American Political Science Review article that focused on residential mobility and voter turnout (Squire et al. 1987), a piece notable not only for its scholarly contribution but its public policy recommendations. Finding that people who move "are less likely to vote for no reason other than the need to reregister and the low priority that this action has," they recommended "linking the maintenance of registration to an action that is usually an intrinsic part of moving that followed from the findings." Because most people have drivers' licenses and update their address with the DMV when they move, linking re-registration to license updates made obvious sense and became the signature provision of the National Voter Registration Act of 1993 (NVRA), often called the "motor voter" law.

In his later work on turnout, Ray worked on assessing the effects of the NVRA (Highton and Wolfinger 1998; Wolfinger and Hoffman 2001), whether jury aversion lowers turnout (Oliver and Wolfinger 1999), and the political implications of different turnout rates across groups (Highton and Wolfinger 2001). In his last article, he analyzed the effects of marriage, divorce, and children on turnout with his son Nick (Wolfinger and Wolfinger 2008).

\section{ACADEMIC HONORS}

Over the course of his career, Ray received many honors recognizing his sizable contributions to scholarship and the discipline of political science. Early in his career he was awarded an APSA Congressional Fellowship and a fellowship at the Center for Advanced Study in the Behavioral Sciences. He was a Guggenheim Fellow in 1965 and a Ford Foundation Faculty Research Fellow in 1970-71. Ray was elected a Fellow of the American Academy of Arts and Sciences in 1983. He retired as the Heller Professor of Political Science at UC Berkeley.

Ray was also an active member of the profession. He participated in the Study of Congress sponsored by the American Political Science Association. He served on the NES Board of Overseers for nine years and chaired it for four. Ray was a longtime member of the American Association of University Professors and served as president of the UC Berkeley chapter for two years. He consulted on the Micronesian independence plebiscites in 1983. He served on the Committee on the Status of Black Americans of the National Academy of Sciences and was a coauthor of the resulting book, A Common Destiny: Blacks and American Society. Ray also served as a visiting consultant to the British Economic and Social Research Council on the design of the British Election Study.

Over his career, Ray mentored and advised an extraordinary number of graduate students. He chaired many dissertations at Stanford and Berkeley, coauthored numerous articles with his students, and advised many more informally. Many of his students have risen to the top ranks of the profession. More important, his students-irrespective of what their career paths have been-feel gratitude and appreciation for the help, attention, and friendship Ray extended to them.

In retirement Ray continued to pursue his long-standing passions, including gardening, farming, and wine drinking. He died peacefully at his home in Berkeley, CA of Alzheimer's disease on February 6, 2015. He is survived by his wife, Barbara Wolfinger, and his son, Nicholas H. Wolfinger, professor of family and consumer studies and adjunct professor of sociology at the University of Utah.

Several years ago, Ray's former students established an endowment in his honor. It supports graduate students engaged in the empirical study of American politics at Berkeley. Contributions may be sent to: "UC-Regents-Wolfinger Family Fund," University of California, Berkeley, University Relations Gift Operations, 2080 Addison Street \#4200, Berkeley, CA 94720-4200.

\footnotetext{
- Benjamin Highton, University of California, Davis -Eric Schickler, University of California, Berkeley -Nicholas H. Wolfinger, University of Utah
} 


\section{R E F E R E N C E S}

Campbell, Angus, Philip E. Converse, Warren E. Miller, and Donald E. Stokes. 1960 The American Voter. New York, NY: John Wiley \& Sons.

Greenstein, Fred I., and Raymond E. Wolfinger. 1958. "The Suburbs and Shifting Party Loyalties." Public Opinion Quarterly 22:473-482.

Highton, Benjamin, and Raymond E. Wolfinger. 1998. "Estimating the Effects of the National Voter Registration Act of 1993." Political Behavior 20:79-104.

. 2001. "The Political Implications of Higher Turnout." British Journal of Political Science 31:179-192.

Keith, Bruce E., David B. Magleby, Candice J. Nelson, Elizabeth Orr, Mark C. Westlye, and Raymond E. Wolfinger. 1977. "The Myth of the Independent Voter." Paper prepared for presentation at the annual meeting of the American Political Science Association. Washington, DC.

Keith, Bruce E., David B. Magleby, Candice J. Nelson, Elizabeth Orr, Mark C. Westlye, and Raymond E. Wolfinger. 1986. "The Partisan Affinities of Independent 'Leaners"' British Journal of Political Science 16:155-185.

Keith, Bruce E., David B. Magleby, Candice J. Nelson, Elizabeth Orr, Mark C. Westlye, and Raymond E. Wolfinger. 1992. The Myth of the Independent Voter. Berkeley, CA: University of California Press.
Oliver, J. Eric. 1999. “Jury Aversion and Voter Turnout.” American Political Science Review 93:147-152.

Pomper, Gerald M. 1977. "The Decline of Party in American Elections." Political Science Quarterly 92:21-41.

Rosenstone, Steven J., and Raymond E. Wolfinger. 1978. "The Effect of Registration Laws on Voter Turnout.” American Political Science Review 72:22-45.

Squire, Peverill, Raymond E. Wolfigner, and David P. Glass. 1987. "Residential Mobility and Voter Turnout." American Political Science Review 81:45-66.

Wolfinger, Nicholas H., and Raymond E. Wolfinger. 2008. "Family Structure and Voter Turnout." Social Forces 86:1,513-28.

Wolfinger, Raymond E. 1963. "The Influence of Precinct Work on Voting Behavior." Public Opinion Quarterly 27:387-398.

. 1965. "The Development and Persistence of Ethnic Voting." American Political Science Review 59:896-908.

- 1974. The Politics of Progress. Englewood Cliffs, NJ: Prentice Hall.

. 2001. "Registering and Voting with Motor Voter." PS: Political Science and Politics 34:85-92.

Wolfinger, Raymond E., and Steven J. Rosenstone. 1980. Who Votes? New Haven, CT: Yale University Press.

\section{Keep PS Informed}

Help us honor the lives and work of political scientists. To submit an In Memoriam tribute, contact PS editorial assistant Drew Meadows atdmeadows@apsanet.org. 